\title{
空気輸送の数值実験 $(\mathbb{I})^{*}$
}

辻裕**

Yutaka TSUJI
前回には，本数值実験の基䃈をなす粒子の反 発について考察し, 速度扣よび回転角速度の衝 突前後の関係式を尊いた。今回は，粒子の運動 方程式や付加任力損失の求め方, さらに粗大粒 子の空気輸送で崜要な役割を果たす異常反発 （不規則反発）について述べる。式，図表およ び文献の番号は，すべて前回からの続きのもの を用いる。

\section{4. 運動方程式}

\section{1 座標系亡粒子の初期条件}

空気輸送に打いては, 粒子供給器からの粒子は, 鉛直 下方の方向で輸送管内へ投入されるのが普通であるの で，図４に示すように座標系を選ぶ。すなわち，管軸に 沿って $x$ 濑，水平方向に $y$ 軸, 鉛直上方に $z$ 軸をとる。 また粒子供給管の管軸と輸送管の管軸との交点を原点に とる。ここで粒子供給管の半径を $R$ とする。粒子の初 期条件ではできるだけ現実に近い状態が望ましい。䈣密 には，供給管からの個々の粒子の落下速度, 落下位置な ぞはずへでランダムな值をとるが，ここでは落下位置だ けをランダム㽬として报い，落下速度は，粒子径，供給

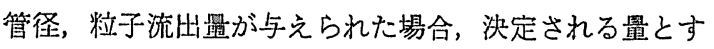
る。

まず，図４の平面図，立面図において，輸送管に投入 される粒子の初期位置を $r ， \theta$ にって与える。したが って $(x, y, z)$ 來慓で，それら初期位置を書き直せば

$$
\begin{aligned}
& x=r_{0} \sin \theta \\
& y=r_{0} \cos \theta \\
& z=\sqrt{(D / 2)^{2}-r_{0}^{2} \cos ^{2} \theta}
\end{aligned}
$$

となる。的を 0 から $R$ までの， $\theta$ を 0 から $2 \pi$ までの一 様乱数で与学る。一般に粒子供給管からの粒子の落下速 度 $\dot{z}$ は，粒子の供給の仕方によって異なり，それらに応

昭和58年1月10日受付

*(1) は本誌 Vol. 20 No.8 p. 514 亿揭楖消

**大阪大学工学部産榮機城工学科 (广565 吹田市山田丘2-1)

TE L 06-877-5111

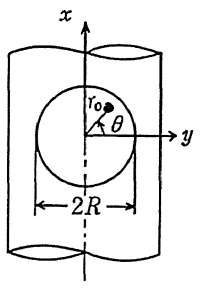

(b) 平面図

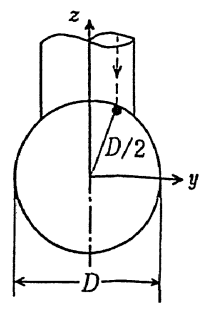

(c) 立面圆
図4座標系

じた与え方をとればよい。ここでは，ホッパーに貯えら れた粒子が粉体オリフィスから落下する場合の Rausch の経験式 ${ }^{13)}$

$$
W=0.5077 D_{0}^{2.745} d^{-0.245} \frac{C \cdot C_{0}}{\sqrt{\tan \varphi}} \rho_{B}
$$

を用いる。ただし上式において

$W:$ 粒子流出質量 $[\mathrm{kg} / \mathrm{s}]$

$D_{0}:$ オリフィス直径 $=2 R[\mathrm{~mm}]$

$d:$ 粒子径 $[\mathrm{mm}]$

$\rho_{B}:$ 粒子かさ密度 $\left[\mathrm{kg} / \mathrm{m}^{3}\right]$

$\varphi:$ 安息角

$C:$ かさ密度の壁面効果補正係数

$C_{0}:$ ホッパー底角に関する補正係数

である。 $D_{0} / d>15 \sim 20$ であれば $C \cdot C_{0}=1$ とおくこと ができる。粒子の落下速度 $\dot{z}$ は，

$$
\dot{z}=\frac{W}{\frac{\pi}{4} D_{0}^{2} \rho_{B}}
$$

で与えられるので, 上式に式 (4.4) を代入すれば,

$$
\dot{z}=0.6465 D_{0}^{0.745} d^{-0.245} / \sqrt{\tan \varphi}
$$

となる。式 (4.4) の下に示した各種の パラメータが与 えられれば，Wは一意的に決定される。したがって管 内空気流量 $Q$ が与兄られれば，混合比 $m$ （粒子・空気 質量・流量比）は決定される。通常の空気輸送ではQが 一定の場合， $m$ の調節は粒子供給量 $W$ を調節すること

* Rausch のもとの式をSI 単位で書き直した。 
そよってなされる。この $m$ の調節を本計算では $D_{0}$ を变 化させることによって行なった。すなわち，混合比的の 定義式

$$
m=\frac{W}{Q}
$$

に式（4.4）を代入し，整理すれば

$$
D_{0}=\left[\frac{m Q d^{0.245} \sqrt{\tan \varphi}}{0.5077}\right]^{\frac{1}{2.745}}
$$

となる。本シミュレーションでは， $Q$ と $m$ を独立なパ ラメータとして任意に与えるので, それらの值に応じ て， $D_{0}$ をその都度变化させた。

\section{2 各種流体力と運動方程式}

一般に粒子の運動は次式によって記述される。

$$
\ddot{M} \ddot{\chi}=F_{d}+F_{l}+F_{g}
$$

上式において，M は粒子の質量， $\chi$ は粒子の位置ベクト ル $\chi=i x+j y+k z, F_{d}, F_{l}, F_{g}$ はそれぞれ流体抵抗,

揚力, 重力による外力である。流体力としては, この他 に回転に対する粘性抵抗も考虑される。

粒子の運動方程式の誘導に执いて用いられるおむな仮 定は次のとおりである。

（1）粒子に作用する流体力に関してはすべて，一様流 中または静止流体中の結果を適用する。

（2）気流の速度分布は $1 / 7$ 乗法則に従い，粒子の存在 による気流速度分布の坐みを無視する。さらに粒子 の運動は気流乱れの影響を受けない。

(3) 粒子相互の衝突を無視する。

流体抵抗ベクトル $\boldsymbol{F}_{d}$ の大きさ $\left|\boldsymbol{F}_{d}\right|$ は

$$
\left|\boldsymbol{F}_{d}\right|=C_{D} A \frac{1}{2} \rho_{a} U^{2}
$$

と与えることができる。ここで $C_{D}$ は抵抗係数， $A$ は粒 子の断面積, $\rho_{a}$ は空気の密度, $U$ は次式で表わされる 粒子と空気の相対速度である。

$$
U=\sqrt{(u-\dot{x})^{2}+\dot{y}^{2}+\dot{z}^{2}}
$$

ただし， $u$ は気流の局所的な時間平均速度である。

$C_{D}$ はレイノルズ数 $R e=U d / \nu$ の関数で, 標準曲線

表 5 式 (4.12) に批る俰数

\begin{tabular}{c|l|l:c}
\hline \multicolumn{1}{c|}{$R e$} & \multicolumn{1}{c|}{$K_{1}$} & \multicolumn{1}{c}{$K_{2}$} & $K_{3}$ \\
\hdashline$R e<0.1$ & 0 & 24 & 0 \\
$0.1<R e<1.0$ & 3.69 & 22.73 & 0.0903 \\
$1.0<R e<10$ & 1.222 & 29.1667 & -3.889 \\
$10<R e<10^{2}$ & 0.6167 & 46.5 & -116.67 \\
$10^{2}<R e<10^{3}$ & 0.3644 & 98.33 & -2778.0 \\
$10^{3}<R e<5 \times 10^{3}$ & 0.365 & 148.62 & -47500.0 \\
\hline
\end{tabular}

Vol. 20 No. 9 (1983)
がすでに多くの教科書に示されている。広籍围のレイノ ルズ数に対しては，次の式が利用できる゙尔。

$$
C_{D}=K_{1}+\frac{K_{2}}{R e}+\frac{K_{3}}{R e^{2}}
$$

$K_{1}, K_{2}, K_{3}$ の值は表 5 に示されている。 $F_{d}$ は相刘速 度ベクトル $(\dot{x}-u) i+\dot{y} j+\dot{z} k$ と逆方向に作用寸るの で, 流体抵抗力の $(x, y, z)$ 方向成分は,

$$
\begin{aligned}
& F_{d_{x}}=\left|F_{d}\right| \frac{(u-\dot{x})}{U}=k M C_{D} U(u-\dot{x}) \\
& F_{d_{y}}=\left|F_{d}\right| \frac{(-\dot{y})}{U}=-k M C_{D} U \dot{y} \\
& F_{d_{x}}=\left|F_{d}\right| \frac{(-\dot{z})}{U}=-k M C_{D} U \dot{z}
\end{aligned}
$$

で与えられる。ただし， $\rho_{s}$ を粒子の真密度として

$$
\left.\begin{array}{l}
M=\frac{\pi}{6} d^{3} \rho_{s} \\
k=\frac{3}{4} \frac{\rho_{a}}{\rho_{s} d}
\end{array}\right\}
$$

である。

次に，回枟に上る掦力についての式を与兄よう。愉选

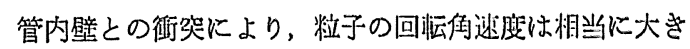
な值，たとえば $10^{3} 〜 10^{4} \mathrm{rad} / \mathrm{s}$ 程度の嗔をとる。この值

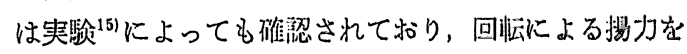

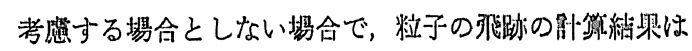

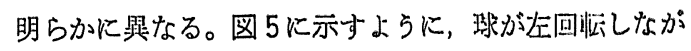

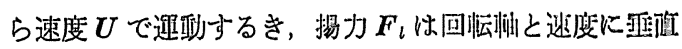
な方向に例く。このとき $\boldsymbol{F}_{l}$ に刘しては

$$
\left|\boldsymbol{F}_{l}\right|=C_{L} A \frac{1}{2} \rho_{a}|U|^{2}
$$

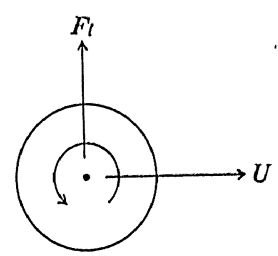

图 5 球の回忶と搨力丁

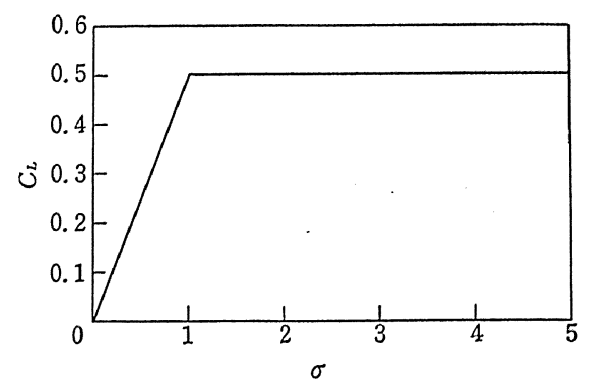

図6掦力保数之通度比の関係 
で揚力倸数 $C_{L}$ が定義され， $C_{L}$ は速度比 $\sigma$

$$
\sigma=\frac{d}{2} \omega /|\boldsymbol{U}|
$$

の関数とおくことができる。 $C_{L}$ と $\sigma$ の関係 ${ }^{16)}$ を図 6 に 示すように, 次式で近似する。

$$
C_{L}=\left\{\begin{array}{ll}
0.5 \sigma & \sigma \leq 1 \\
0.5 & \sigma>1
\end{array}\right\}
$$

翰送管内の球の場合, $\boldsymbol{U}, \omega$ とも $x, y, z$ の 3 方向成 分を有するが，すべての成分を考䉥すると複傕になるの で，以下の上うに近似的に扱う。すなわち，相対速度心 クトルとしては

$$
\boldsymbol{U}=(u-\dot{x}) \boldsymbol{i}
$$

のみを考琶し，回枟角速度ベクトルを

$$
\omega=\omega_{y} \boldsymbol{j}+\omega_{z} k
$$

とおく。つまり $(y, z)$ 平面上の運動にのみ揚力を考 虑する。以上のように仮定すれば，揚力の大きさ $\left|\boldsymbol{F}_{l}\right|$ お よび $\sigma$ は次式で与えられる。

$$
\begin{aligned}
& \left|F_{l}\right|=C_{L} \frac{1}{8} \pi d^{2} \rho_{a}(u-\dot{x})^{2} \\
& \sigma=\frac{\left|\omega_{l} j+\omega_{z} k\right| d}{2(u-\dot{x})}
\end{aligned}
$$

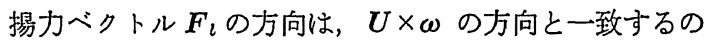
で, $U \times \omega$ の単位方向ベクトルeを

$$
\boldsymbol{e}=e_{y} j+e_{z} k
$$

とおけば

$$
\boldsymbol{F}_{\iota}=\left|\boldsymbol{F}_{\iota}\right| e_{y} \boldsymbol{j}+\left|\boldsymbol{F}_{\iota}\right| e_{z} \boldsymbol{k}
$$

となる。 $e_{y}, e_{z}$ は式 (4.18)，(4.19) より

$$
\left.\begin{array}{l}
e_{y}=\frac{(u-\dot{x}) \omega_{z}}{|u-\dot{x}| \sqrt{\omega_{y}{ }^{2}+\omega_{z}{ }^{2}}} \\
e_{z}=\frac{(u-\dot{x}) \omega_{y}}{|u-\dot{x}| \sqrt{\omega_{y}{ }^{2}+\omega_{z}{ }^{2}}}
\end{array}\right\}
$$

である。式 (4.20)を式 (4.23) へ代入すれば， $\boldsymbol{F}_{l}$ の 各成分が次式で与えられる。

$$
\left.\begin{array}{l}
F_{l_{x}}=0 \\
F_{l_{y}}=C_{L_{v} k M(u-\dot{x})^{2}} \\
F_{l_{z}}=C_{L_{z}} k M(u-\dot{x})^{2}
\end{array}\right\}
$$

ただし

$$
\left.\begin{array}{l}
C_{L_{y}}=C_{L} e_{y} \\
C_{L_{z}}=C_{L} e_{z}
\end{array}\right\}
$$

である。

粒子に働く重力 $F_{g}$ は

$$
\boldsymbol{F}_{0}=-g M k
$$

で与えられる。

式 (4.13)，(4.25)，(4.27）を式 (4.9) へ代入し整 理すれば，粒子の運動方程式は次式となる。

$$
\left[\begin{array}{c}
\ddot{x} \\
\ddot{y} \\
\ddot{z}
\end{array}\right]=\left[\begin{array}{c}
k C_{D} U(u-\dot{x}) \\
-k C_{D} U \dot{y} \\
-k C_{D} U \dot{z}
\end{array}\right]+\left[\begin{array}{c}
0 \\
k C_{L_{y}}(u-\dot{x})^{2} \\
k C_{L_{z}}(u-\dot{x})^{2}
\end{array}\right]+\left[\begin{array}{r}
0 \\
0 \\
-g
\end{array}\right]
$$

$k$ は式 (4.14), $C_{D}$ は式 (4.12) と表 $5, C_{L_{y}}, C_{L_{z}}$ は 式 (4.26) と式 (4.17)，(4.21）より決定される。上式 を積分すれば粒子の飛跡が求まるが，積分は数值積分 法，たとえばルンゲ・クッタ法などを用いて行なう必要 がある。

\section{3 圧力損失}

運動方程式によって粒子の運動を求めるだけであれ ば，本手法の実用的洒值は低い。なぜなら設計技術者に とって知りたい量は压力損失であるからである。そこで 本節では圧力損失の求め方について述べる。

区間 $d x$ における全圧力損失 $d p$ は，気流のみによる 圧力損失 $d p_{a}$ と粒子による付加圧力損失 $d p_{s}$ の和とし $\tau$,

$$
d p=d p_{a}+d p_{s}
$$

とおく。d $p_{a}$ に対しては単相流の結果，たとえばブラ ジゥスの管摩擦公式

$$
\left.\begin{array}{l}
\frac{d p_{a}}{d x}=\frac{\lambda}{D} \frac{1}{2} \rho_{a} u^{2} \\
\lambda=\frac{0.3164}{R e^{\frac{1}{4}}}
\end{array}\right\}
$$

が利用できる。

付加圧力損失 $d p_{s}$ は粒子に働く流体抵抗の反作用 と して得られるが，具体的に式を導くため図 7 に示すよう に，断面内の粒子の分布を一様と仮定し，現象を一次元 的に扱らことにする。図に执いて $d x$ は，粒子が $d t$ 時 間に進む距離

$$
d x=\dot{x} d t
$$

とし，区間 $d x$ に含まれる粒子の個数を $N$ とする。付加 圧力損失 $d p_{s}$ と管断面積 $S$ の積 $d p_{s} \cdot S$ は, 運動量の定

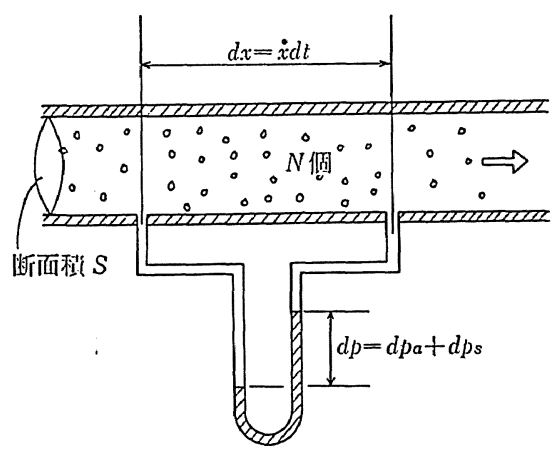

図 7 空気輸送される粒子群 
理により，流体が粒子群に与えた力，すなわち流体抵抗 に等しい。したがって

$$
d p_{s} \cdot S=-F_{d x} \cdot N
$$

となる。普通, 空気輸送の取扱いにおいては, 粒子の個 数 $N$ よりも粒子の質量流量や混合比（粒子と空気の質量 流量比） $m$ がパラメータにとられるので，ここでも $N$ 代わりに $m$ を用いて式を整理する。 $d t$ 時間に輸送され る粒子の質量は $M N$ であり（ $M$ は粒子 1 つ当りの質量 で式 (4.14)により与えられる), 流体の質量は $\rho_{a} S \bar{u} d t$ である。ただし 混合比 $m$ の定義

$$
m=\frac{M N}{\rho_{a} S \bar{u} d t}
$$

より

$$
N=m \frac{\rho_{a} S \bar{u} d t}{M}
$$

となる。式 (4.13)，(4.34)を式 (4.32) へ代入すれば

$$
\frac{d p_{s}}{d t}=-k \rho_{a} \bar{u} C_{D} U(u-\dot{x}) m
$$

が得られる。式 (4.28)，(4.35) において時間軸 $t$ と空 間軸 $x$ は式 (4.31) によって変換される。運動方 程 式 （4.28）と連立して, 式 (4.35)，の積分を行なえば，付 加圧力損失の流れ方向の変化が求まる。ただし，このよ らにして求めた付加圧力損失の值は 1 個粒子の值に粒子 個数を掛けたものに相当するので付加圧力損失の実測值 と比較するには，多数の粒子に対し同様の計算を実行 し，個々の粒子に対し得られた $d p_{s}$ の值を平均する必 要がある。著者の経験によれば，30～50個程度の粒子の 計算によって実用的な意味で十分収束するようである。

\section{4 粒子の回転の粘性減衰}

粒子の回転の粘性減衰梳以下の理由によって考慮する 必要がある。前に述べたように空気輸送される粒子は $10^{3} \sim 10^{4} \mathrm{rad} / \mathrm{s}$ 程度の高速回転をしているが，回転数の 無限の增加があり得ないことはいうまでもない。しか し，数值荂験において回䎐の増加を抑制する因子を考慮 しない場合, 回転数は衝突の度に增え, 流れ方向に粒子 の回転数は増加しつづける。とくに粒子の反発が管の下 半面のみで繰り返される場合に, この傾向が顕著であ る。前回示した衝撃運動方程式の解からもわかるよう に，一般に衝突後の粒子速度は回転による影響 も受け る。本数值実験では回転が粒子速度を增加させる傾向を もつため, 回転の減衰がない場合, 空気との相対速度が 小さくなり，圧力損失などが実際と合わなくなる。

著者が調べた限りでは, 球の回転の粘性減衰について は，静止流体中に和いて得られた結果しか見あたらない ので、ここではそれを利用する。角速度 $\omega て ゙$ 回転する
表 6 式 (4.37) に批る保数

\begin{tabular}{c|c|c}
\hline$R$ & $C_{1}$ & $C_{2}$ \\
\hline $10<R<20$ & 5.32 & 37.2 \\
$20<R<50$ & 6.44 & 32.2 \\
$50<R<100$ & 6.45 & 32.1 \\
\hline
\end{tabular}

球に働くトルク $T$ はストークス近似が成り立つ侽合， 次の理論解を特つ。

$$
T=-8 \pi \mu a^{3} \omega
$$

ただし， $\mu$ は流体の粘度， $a$ は粒子の半径 $d / 2$ である。 しかし，粗大粒子の場合にはストークス近似を用いるこ そができないので，広䈖围のレイノルズ数 $R=a^{2} \omega / \nu に$ 対し成立する次の式 ${ }^{17)}$ を邂用する。

$$
T=-\frac{1}{2} \rho_{a} a^{5} \omega^{2}\left(C_{1} R^{-\frac{1}{2}}+C_{2} R^{-1}\right)
$$

表 6 に $C_{1}$ と $C_{2}$ の值を示す。粒子の惯性モーメントを $I$ とすれば，粘性による角速度の变化は

$$
I \dot{\omega}=T
$$

で与えられる。ただし，

$$
I=\frac{8}{15} \pi \rho_{s} a^{5}
$$

である。微分方程式 (4.38) により，路突から次の衙突 までの間の角速度の变化量が求まる。7嫴に执いて結果 を示すが，粘性による減衰を式 (4.37)，(4.38）で洘䐵 することにより，実測值と同程度の回忶数に括ちつくこ とが確認されている。

\section{5. 異常反発}

\section{1 異常反発のモデル}

前章までの説明で，空気㡏送シミュレーションの淮俌 がほとんどでき上ったことになるが，ここでさらに濐虚 すべき重要な現象が潔題に示した巽常反発である。前新 までの計算モデルでは，水平な直管に捄いて粒子の反発 が下の壁で単純に絽り返されると，図８に示すように粒 子の壁面からのは齐かえり距離は減少の一途をたどり， いずれの粒子も管底をしゅう動する結果におちちい。し

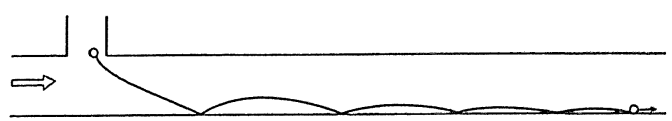

图 8 異常反発をしない粒子の遇㳩

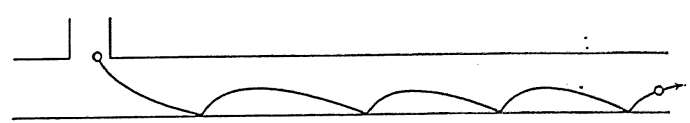

图9異常反発をする粒子の運的 
かし実際の空気輸送を観察すれば，図 9 に示すように粒 子は区発を絽り返しながら飛翔しつづける。少くとも粗 大粒子の空気輸送の場合, 回転による揚力, 乱れ, さら に気流速度勾配による揚力などの流体力は，乙心ら動を 妨げる原因にはなり得ない。長い水平管において粒子が 飛翔しつづけるのは, 緟突後の粒子の速度の半径方向成 分（壁面に垂直な方向）が衰えないためである。ここで は,このような反発を異常反発と呼ぶ。

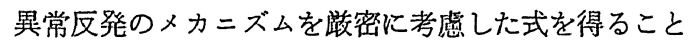
は困難であるので，モデルを作ることにする。そのよう なモデルとしては，いろいろなるのが考えられる。たと

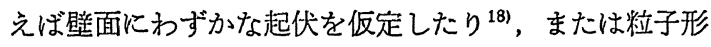
状を完全球からわずかに程ませるだけで151，粒子が定常 的に反発を繰り返すことが，本稿と同様の数值実験によ って示されている。ここでは，仮想壁面を導入すること によって粒子と壁面の反発を操作する方法を述べる。す なわち，長い水平管内で定常的な反発を可能にするた め，管壁に対する粒子の入射角クがある值及以下になれ ば，壁面は図10の破線で示される迎え角 $\alpha$ をつ壁面 に置きかえられる。この迎え角 $\alpha$ と入射角 $\eta$ の関係を勾 配 $\delta$ を用いて次式で仮定する。

$$
\left.\begin{array}{ll}
\alpha=-\delta(\eta-\beta) & \eta<\beta \\
\alpha=0 & \eta \geq \beta
\end{array}\right\}
$$

上式から筫かれる結果と同様の結果が，粒子の反発実

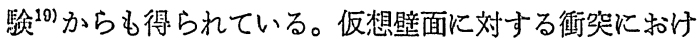
る粒子速度や回枟角速度の变化の計算には 3 章（前回第 8 号)で求めた関係式をそのまま使えばよい。粒子がこ の上うな仮想譬面と反発する場合，もとの壁面から測っ た反射觕グはクよりきくなるので，速度の半径方向 成分は敦えず粒子の反発はいつまでも続く。

㷂際の空気㡏送と同じような粒子佯の分布を得るに は，仮想䲞面が流れ方向（管䡃方向）に $\alpha$ の角度を持 つだけでなく、ささらに周方向にも

$$
-r_{0}<\gamma<r_{0}
$$

の簛围の角度 $r$ を持つと仮定し， $r$ を乱数によって衝突

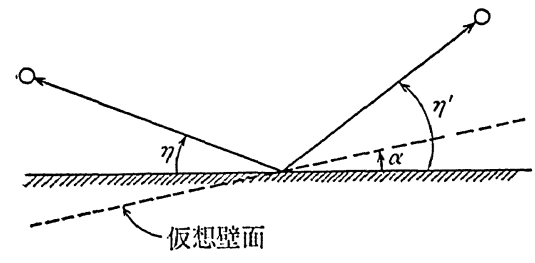

図10 異常反発に打ける仮想壁面

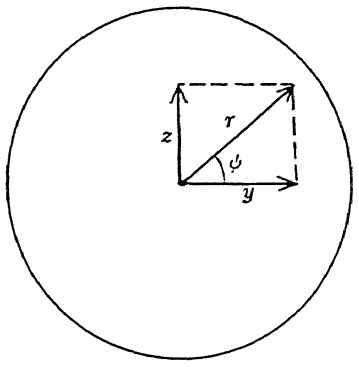

図11 直角座摽と曲座摽

の度に与える必要がある。「による不規則性を与えた理 由は，角度 $\alpha$ のみによる反発の操作では，距離が長く なると粒子の分布が一ケ所に集中し，現実の分布と合わ

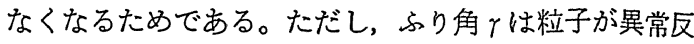
発を行なら場合のみ考慮するだけで十分である。 70などの決定はまったく経騟的であり，それについて は 7 章で述べる。

\section{2 座標変換}

粒子の空間運動は図 4に示したように0ーxyz 座標系 を用いて記述されており，一方衝突前後の関係について は，図1（前回第 8 号）に示す衙突平面上に設定された $0-X Y Z$ 座標系を用いてその解が表わされている。そ のため $2 つ の$ 座標系に対する粒子の速度および回転角速 度の変換式が必要となる。まず異常反発がない場合につ いて変換式を示し，そのあと異常反発を考慮に入れる。

$x$ とXは同じであるので

$$
\left.\begin{array}{l}
V_{X}{ }^{(0)}=\dot{x} \\
\omega_{X}{ }^{(0)}=\omega_{x}
\end{array}\right\}
$$

である。 $\left(V_{Y}{ }^{(0)}, V_{Z}{ }^{(0)}\right)$ 成分と $(\dot{y}, \dot{z})$ 成分の変換式を 薄くため，図11に示す管断面において直角座標 $(y, z)$ と曲座標 $(r, \psi)$ を考える。

$$
\left.\begin{array}{l}
y=r \cos \psi \\
z=r \sin \psi
\end{array}\right\}
$$

なる関係と

$$
\left.\begin{array}{rl}
-V_{Y}{ }^{(0)} & =\dot{r} \\
V_{Z}{ }^{(0)} & =r \dot{\psi}
\end{array}\right\}
$$

より

$$
\left.\begin{array}{rl}
-V_{Y}{ }^{(0)} & =\dot{y} \cos \psi+\dot{z} \sin \psi \\
V_{z}{ }^{(0)} & =-\dot{y} \sin \psi+\dot{z} \cos \psi
\end{array}\right\}
$$

が容易に得られる。 $V_{Y}{ }^{(0)}$ に負符号 (一) が付くのは, $r$ の方向と $Y$ の方向が逆にとられているためである。式 （5.3）と（5.6）をまとめて次のように書くこともでき る。

$$
V^{(0)}=\dot{A \dot{\chi}}
$$

回䎐角速度についても同様に 


$$
\omega^{(0)}=A \omega_{\chi}
$$

となる。ただし

$$
\begin{aligned}
& \boldsymbol{V}^{(0)}=\left(V_{X}{ }^{(0)}, V_{Y}{ }^{(0)}, V_{Z}^{(0)}\right) \\
& \omega^{(0)}=\left(\omega_{X}{ }^{(0)}, \omega_{Y}{ }^{(0)}, \omega_{Z}{ }^{(0)}\right) \\
& \dot{\chi}=(\dot{x}, \dot{y}, \dot{z}) \\
& \omega_{x}=\left(\omega_{x}, \omega_{y}, \omega_{z}\right) \\
& A=\left[\begin{array}{ccc}
1 & 0 & 0 \\
0 & -\cos \psi & -\sin \psi \\
0 & -\sin \psi & \cos \psi
\end{array}\right] \\
& \phi=\tan ^{-1} z / y
\end{aligned}
$$

である。異常反発を考慮しないならば，上式によって $(X, Y, Z)$ 座標に対応する衝突前の粒子速度, 回転角 速度が求まるので，表 2 （前回第 8 号）に与えた式に従 っ , 衝突後の $\left(V_{X}, V_{Y}, V_{Z}\right),\left(\omega_{X}, \omega_{Y}, \omega_{Z}\right)$ が得 られる。( $\left(V_{X}, V_{Y}, V_{Z}\right)$ および $\left(\omega_{X}, \omega_{Y}, \omega_{Z}\right)$ が得ら れれば，次に式 (5.7)，(5.8) の逆変換により $(\dot{x}, \dot{y}$, z) および $\left(\omega_{x}, \omega_{y}, \omega_{z}\right)$ に計算し直し，再び運動方程 式や回転粘性減衰式に基づいて次の衝突までの粒子の運 動を計算すればよい。

次に異常反発がある場合を考えよう。本稿のモデルで は，異常反発は真の壁面に対し傾いた仮想壁面に粒子が 衝突することによって引き起こされる。衝突問題の際に

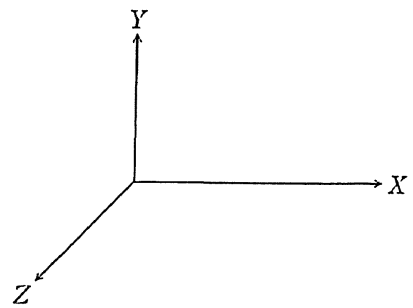

図12 衙突問題に扣ける座鳔系

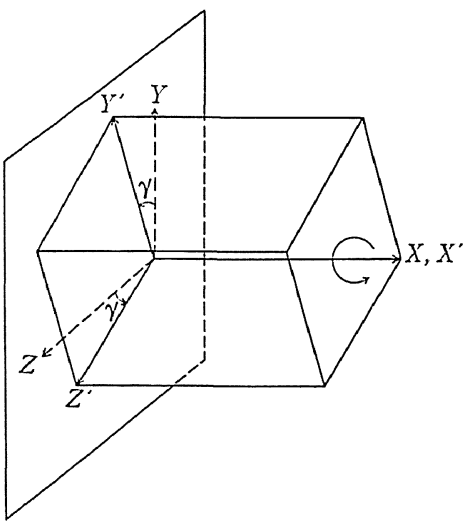

図13 ふり角个による回転

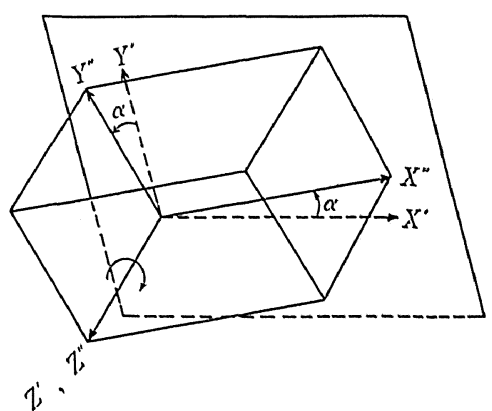

図14迎南 $\alpha$ による回朊

用いた座標系を図12に改めて示す。因に扰いてXは管㑚

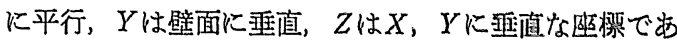

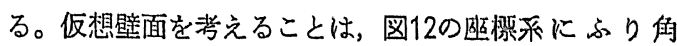
$r$, 迎穴角 $\alpha$ の回転を与克，上に求めた $\left(V_{X}{ }^{(0)}, V_{X^{\prime}}{ }^{(0)}\right.$ ， $\left.V_{Z}{ }^{(0)}\right) ，\left(\omega_{X}{ }^{(0)} ， \omega_{Y}{ }^{(0)}, \omega_{Z}{ }^{(0)}\right)$ をそのような回枟を施こ された座標系の成分として变換し，それらを琎知前の速 度，角速度として扱らことと等仙である。

まず， $(X, Y, Z)$ 幽標系に刘し，图13に示少上らに $X$ を軸に $(Y, Z)$ 㑤面内で角度

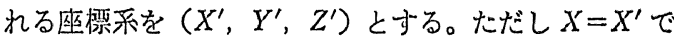
ある。したがって $\left(X^{\prime}, Y^{\prime} ， Z^{\prime}\right)$ 幽標に拈ける速度成 分は次式で与兄られる。

$$
\left[\begin{array}{l}
V_{X^{(0)}} \\
V_{Y}{ }^{(0)} \\
V_{Z}{ }^{(0)}
\end{array}\right]=\left[\begin{array}{ccc}
1 & 0 & 0 \\
0 & \cos \gamma & \sin \gamma \\
0 & -\sin \gamma & \cos \gamma
\end{array}\right]\left[\begin{array}{l}
V_{X}{ }^{(0)} \\
V_{Y^{(0)}} \\
V_{Z}{ }^{(0)}
\end{array}\right]
$$

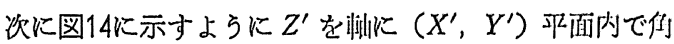

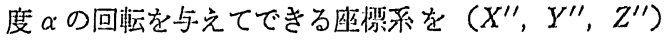
とする。ただし $Z^{\prime}=Z^{\prime \prime}$ である。( $\left(X^{\prime \prime}, Y^{\prime \prime}, Z^{\prime \prime}\right)$ 幽 標采に护的速度成分は

$$
\left[\begin{array}{l}
V_{X}{ }^{(0) \prime \prime} \\
V_{Y}(0) \prime \prime \\
V_{Z}(0) \prime \prime
\end{array}\right]=\left[\begin{array}{rcc}
\cos \alpha & \sin \alpha & 0 \\
-\sin \alpha & \cos \alpha & 0 \\
0 & 0 & 1
\end{array}\right]\left[\begin{array}{l}
V_{X}{ }^{(0) \prime} \\
V_{Y}(0) \prime \\
V_{Z}{ }^{(0) \prime}
\end{array}\right]
$$

で与えられる。回転角速度についても式(5.10)，(5.11) とまったく同じ变換行列を使うことができるので，結局 ベクトル $V^{(0) \prime \prime}=\left(V_{X}{ }^{(0) \prime \prime}, V_{Y}^{(0) \prime \prime}, V_{Z}^{(0) \prime \prime}\right)$ 特よび $\omega^{(0) \prime \prime}=\left(\omega_{X}{ }^{(0) \prime \prime}, \omega_{Y}{ }^{(0) \prime \prime}, \omega_{Z}{ }^{(0) \prime \prime}\right)$ \& $V^{(0)}=\left(V_{X}{ }^{(0)}\right.$, $\left.V_{Y}{ }^{(0)}, V_{Z}{ }^{(0)}\right), \omega^{(0)}=\left(\omega_{X}{ }^{(0)}, \omega_{Y}{ }^{(0)}, \omega_{Z}{ }^{(0)}\right)$ \&次式で阙 係づけられる。

$$
\left.\begin{array}{l}
V^{(0) \prime \prime}=B V^{(0)} \\
\omega^{(0) \prime \prime}=B \omega^{(0)}
\end{array}\right\}
$$

ただし，

$$
B=\left[\begin{array}{ccc}
\cos \alpha & \sin \alpha & 0 \\
-\sin \alpha & \cos \alpha & 0 \\
0 & 0 & 1
\end{array}\right]\left[\begin{array}{ccc}
1 & 0 & 0 \\
0 & \cos \gamma & \sin \gamma \\
0 & -\sin \gamma & \cos \gamma
\end{array}\right]
$$




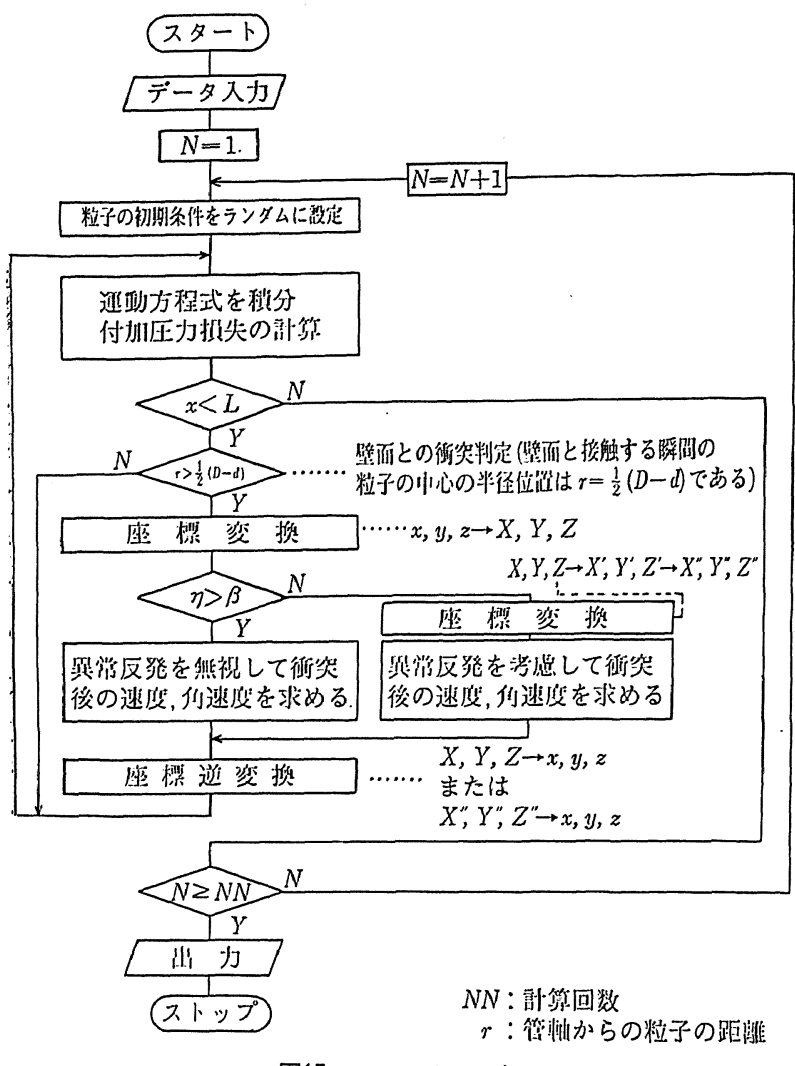

図15フローチャート

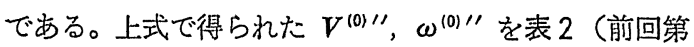

支

13) Zenz, F.A. and D.F. Othmer: Fluidization and Fluid-Particle Systems, Reinhold, 140 (1960)

14) Morsi, S.A. and A.J. Alexander: J. Fluid Mech., 55-2, 193 (1972)

15) Matsumoto, S. and S. Saito: J. Chem. Eng. Japan, $3-1,83(1970)$
8 号) の $V^{(0)}, \omega^{(0)}$ の代わりに代入すれば $V, \omega か ゙$ 求 まるが,これは仮想壁面に衝突した場合の值であり， これを $(x, y, z)$ 座標に変換するには次のような 逆変換を施こす必要がある。

$$
\left.\begin{array}{l}
\dot{\chi}=A^{-1} B^{-1} V \\
\omega_{x}=A^{-1} B^{-1} \omega
\end{array}\right\}
$$

ただし， $A^{-1} ， B^{-1}$ はそれぞれ行列 $A, B$ の逆行列 である。

本手法では，粒子は常に異常反発するのではな く，粒子の壁面に対する入射角クがある值々よりる 小さい場合に限っている。

$$
\eta<\beta
$$

したがって異常反発を起こさせるかどうかの判定の

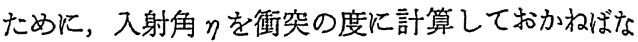
らない。クは次式で与えられる。

$$
\eta=\tan ^{-1} \frac{-V_{Y}{ }^{(0)}}{\sqrt{V_{X}{ }^{(0)}+V_{Z}^{(0) 2}}}
$$

\section{6. 数 值計算}

以上で数值実鈳を行ならためのすべての準備が完 了したことになり，次の段階はプログラミングであ る。どのような問題に応用するかによって一般にプ ログラムは大きく変る。最も簡単な長さ $L$ の直管の 場合のフローチャートの一例を図15に示す。

次回は，直管の場合打よびベンドを有する場合に 得た計算例を示す。

献

16）谷一郎: 科学, 24-9, 405 (1950)

17) Dennis, S.C.R., S. N. Singh and D.B. Ingham: J. Fluid Mech., 101-2, 257 (1980)

18) Matsumoto, S. and S. Saito: J. Chem, Eng. Japan, $3-2,223$ (1970)

19) Muschelknautz, E. : VDI-Forsch.-Heft. 476 (1959) 